\title{
Yapısal Atıkların Geri Dönüşüm Sorunu ve Türkiye'deki Durumun Mevzuat Bakımından Değerlendirilmesi
}

\author{
Ceyda Buzkan ${ }^{1} \oplus$, Onur Erman ${ }^{1, \oplus}$ \\ ${ }^{1}$ Çukurova Üniversitesi, Mimarlık Fakültesi, Mimarlık Bölümü, 01330, Adana.

\section{Özet}

Artan nüfusla birlikte çoğalan yapılaşma faaliyeti sonucunda oluşan atıklar yapısal atık olarak tanımlanmaktadır. Çeşitli boyutlarda çevresel sorunlara sebep olan yapısal atıkların, doğal kaynakların tüketilmesinin azaltılması ve verimli kullanılması için geri dönüşı̈̈rülmesi kaçınılmazdır. Atıkların geri dönüşümünün sürdürülebilir çevre kalitesi, doğal kaynakların korunumunun yanı sıra sosyal ve ekonomik refah bakımından etkili olduğu bilinmektedir. Dünya Çevre ve Kalkınma Komisyonu raporu ile tanıştı̆̆ımız sürdürülebilirlik kavramını, inşaat sektörüne adapte etmek için bazı ülkeler yasal düzenlemeler ve uygulamalar geliştirmiştir. Ülkemizde de bu kapsamda yasal düzenlemeler yürürlükte olmasina rağmen istenilen değerde geri dönüşüm verileri sağlanamamaktadır. 2004 yılında yürürlüğe girmiş olan yapısal atıkların yönetimine ilişkin yönetmelik hali hazırda uygulamada olmasına rağmen geri dönüşümün yaygınlaştırılması ve çevre korunumu için uygulamaların ve düzenlemelerin yetersiz kaldı̆̆g düşünülmektedir. Çalışma özellikle son yıllarda hızla artan yapılaşma faaliyetleri sonucunda ortaya çıkan yapısal atık sorununa değinerek, ülkemizdeki durumu mevzuat bakımından değerlendirmeye çalışmıştır. Çalışma kapsamında AB ve diğer gelişmiş ülkeler ile ülkemizdeki mevzuat incelenerek uygulamaya yönelik gereksinimler belirlenmiştir.

\section{$\underline{\text { Anahtar Sözcükler }}$}

Yapısal Atık, Atık Yönetimi, Geri Dönüşüm, Çevre

\section{Construction \& Demolition Waste Recycling Problem and Evaluation of the Situation in Turkey in Terms of Legislation}

\begin{abstract}
Wastes resulting from the accelerated construction activity with the increasing population are defined as construction and demolition $(C \& D)$ waste. $C \& D$ wastes that cause environmental problems of various sizes should be recycled to reduce the consumption of natural resources and to use them efficiently. Recycling of waste is known to be effective in terms of sustainable environmental quality, conservation of natural resources as well as social and economic prosperity. Some countries have developed legislation and practices, with the aim of adaptation of the sustainability concept, which was mentioned for the first time in World Commission on Environment and Development Report, into the construction sector. In our country, although legal regulations in this scope are in force, no recycling data can be provided at the desired value. The regulation on the recycling of $C \& D$ wastes that came into force in 2004 is already in practice; nevertheless, it is considered that the practices and arrangements for the promotion of recycling and the protection of the environment are insufficient. It has been tried to evaluate the situation in our country in terms of legislation by touching on the C\&D waste problem that emerged as a result of the rapidly increasing construction activities in recent years. Within the scope of the study, the EU and other developed countries, and the legislation in our country are being examined and the requirements for implementation are stated.
\end{abstract}

$\underline{\text { Keywords }}$

Construction and Demolition Waste, Waste Management, Recycling, Environment

\section{Giriş}

Sürdürülebilirlik kavramı öncesi tüm dünya ülkelerinin ekonomik sistemleri, doğal kaynakların tükenmesi prensibine dayanmaktadır. Sürdürülebilirlik kavramı ilk kez Birleşmiş Milletler çerçevesinde faaliyet gösteren Dünya Çevre ve Kalkınma Komisyonu'nun 1987'de yayınladığı “Ortak Geleceğimiz” konulu rapor aracılığıly gündeme girmiştir. Rapor sürdürülebilirliğin gerekliliğini, "Insanlık; doğanın gelecek kuşakların gereksinimlerine cevap verme yeteneğini tehlikeye atmadan, günlük ihtiyaçları temin ederek kalkınmayı sürdürülebilir kılma yeteneğine sahiptir." şeklinde belirtmiştir (URL-1 2018). Böylece doğal kaynak tüketimini azaltmaya ve oluşan atıkları dönüştürmeye yönelik çalışmalar ve yasal düzenlemeler yapılmaya başlanmıştır. 
Ülkemizde özellikle yapısal atık kontrolü konusunda yapılan yasal düzenlemelerin başlıcaları çerçeve yasa niteliğinde olan 1983 tarihli ve 2872 sayılı Çevre Kanunu, oldukça geniş kapsama sahip olan ve 2004 yılında yayınlanan Hafriyat Toprağı, İnşaat ve Yıkıntı Atıklarının Kontrolü Yönetmeliği ve 2015 yılında yayınlanan Atık Yönetimi Yönetmeliği’dir. Ülkemizde yasal mevzuata ilişkin son yıllarda yapılan düzenlemeler konusunda ise Avrupa Birliği (AB) mevzuatına uyum çalışmalarının etkili olduğu görülmektedir. 2015 yılında yayınlanan Atık Yönetimi Yönetmeliği Avrupa Birliği 2008/98/AT sayılı Atık Çerçeve Direktifi'ne uyumlu olarak hazırlanmıştır. Bu yönetmelikle doğal kaynak kullanımının azaltılması hedefiyle atık yönetimi planlaması ve atık sınıflanması yapılmıştır. Atık yönetiminde en önemli unsur atık oluşumunu önlemek olmakla birlikte, yeniden kullanım ve atıkların geri dönüşümü de sürecin önemli bir parçasıdır. Bu süreç içinde, atıkların geri kazanımının sağlanmadan bertaraf edilmesi hem hammadde hem de enerji kullanımı bakımından ciddi kaynak kayıpların yaşanmasının (URL-2 2018) yanı sıra ekosistem üzerinde de olumsuz etkilere sebep olmaktadır. Dünya nüfusunun ekosistemden talep ettiği kaynağın büyüklüğü ve bu kaynağın ne kadarının geri kazanılması gerektiğini belirlemek için, Ekolojik Ayak izi yöntemi kullanılmaktadır. Türkiye Ekolojik Ayakizi’nin yıllara göre değerlerine bakıldığında sürdürülebilirlik kapsamlı çalışmaların önemi artmaktadır (URL-3 2018).

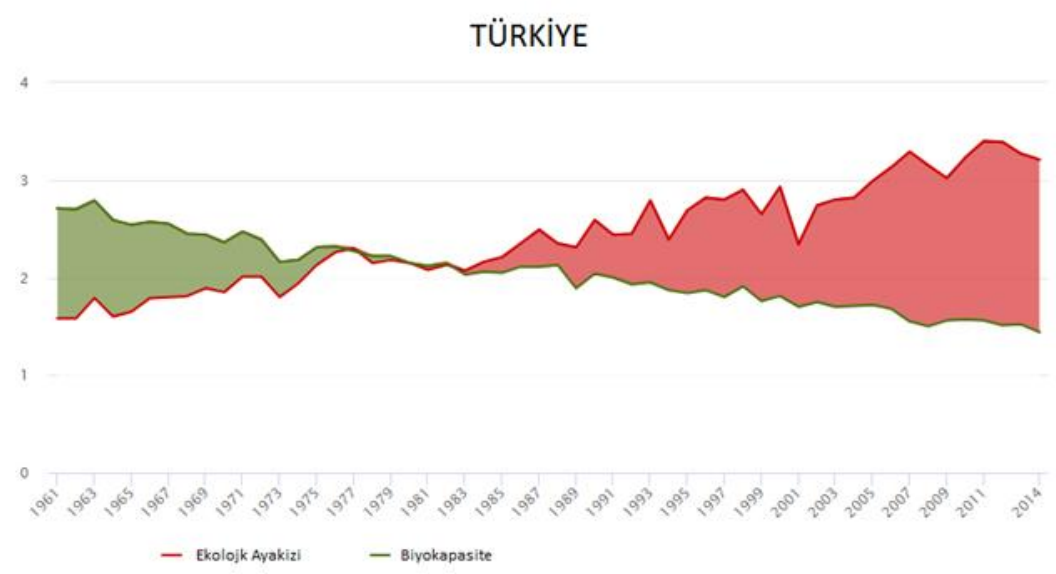

Şekil 1: Türkiye'nin yıllara göre Ekolojik Ayak İi değerleri (URL-4 2018)

Şekil 1 incelediğinde 1980'li yıllarla birlikte ülkemiz için tehlike sinyallerinin görülmeye başlandığı söylenebilir. Bu yıllar ülke nüfusumuzun arttığı ve köylerden özellikle büyükşehirlere göçün arttığı yıllar olarak öne çıkmaktadır. Bu dönemde köyden kente doğru göç, hızlı kentleşme ve yapılaşma sonucu ekolojik üretim azalmış şehirlerdeki üst yapı ve altyapı çalışmaları artmıştır. Artan tüketim ve geri dönüşümsüz yapılaşma atıkları kaçınılmaz olarak doğal kaynakların kirlenmesine sebep olmaya başlamıştır. Şekil 2 ve Şekil 3'de görüldüğü gibi uygulama ve denetim eksikliği kaçak yollarla dökülen atıkların çevreye verdiği zararı göstermektedir.

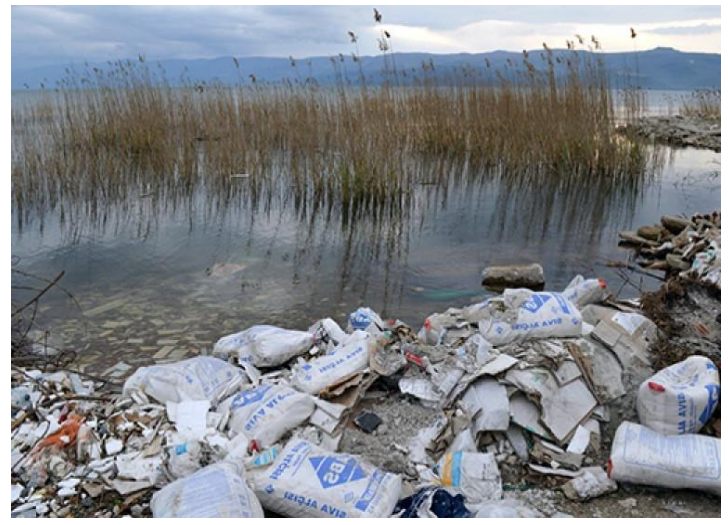

Şekil 2: Iznik Gölü (URL-5 2018)

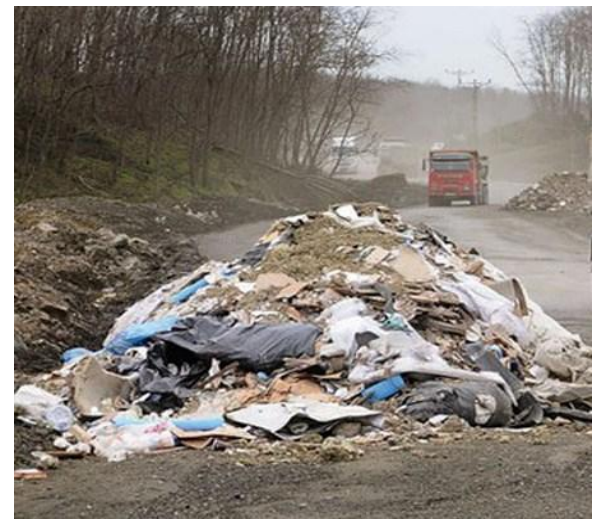

Şekil 3: Belgrad Ormanı (URL-6 2018)

Hafriyat Toprağı, İnşaat ve Yıkıntı Atıklarının Kontrolü Yönetmeliği'ne göre bu atıklar, inşaat atıkları ve yıkıntı atıklar olarak isimlendirilmiştir. Yönetmeliğe göre inşaat atıkları; "konut, bina, köprü, yol ve benzeri alt ve üst yapıların yapımı esnasında ortaya çıkan atıklar", yıkıntı atıklar ise "konut, bina, köprü, yol ve benzeri alt ve üst yapıların tamiratı, tadilatı, yenilenmesi, yıkımı veya doğal bir afet sonucunda ortaya çıkan atıklar” olarak tanımlamaktadır (HİYAKY 2004). Literatür taraması kapsamında bu atıkların yapısal atık olarak da isimlendirildiği görülmektedir. 
Limoncu ve Biçer Özkun (2012)'na göre yapısal atıklar; “yapının tasarlanmasına karar verilmesiyle başlayan ve yapının çeşitli nedenlerle yok olması, diğer bir ifadeyle ‘ömrünü tamamlaması’ sürecinde (ürün ölçeğinden yapı ölçeğine kadar) ortaya çıkan atıklar” olarak tanımlamıştır (Salgın 2015). Bu makalede daha kapsamlı tanım olan yapısal atık tanımının kullanımı tercih edilmiştir. Ülkemizde oluşan yapısal atıkların miktarı, denetim kurumları olmasına rağmen denetim ve izleme faaliyetlerinin yetersizliğinden dolayı kesin olarak tespit edilememektedir. Öte yandan son yıllarda yapısal atık miktarının artış eğiliminde olduğu, özellikle 2012 yılında yürürlüğe giren Afet Riski Altındaki Alanların Dönüştürülmesi Hakkında Kanun ile bu artışın desteklendiği düşünülmektedir. Bu kanun kapsamında 20 yıllık süreç içinde 6,5 milyon yapının yıkılması beklenirken (Kotan 2016), bugüne kadar 592 bin konutun dönüşümü gerçekleşmiştir (URL-7 2018).Bazı illerimizin valiliklerince yayınlanan 2017 İl Çevre Durum Raporlarına göre hafriyat toprağı ve inşaat/yıkıntı atık miktarları Tablo 1'de verilmektedir.

Tablo 1: Bazı Illerin 2017 yılı hafriyat toprağı ve inşaat/yıkıntı atık miktarları (URL-8 2017; URL-9 2017; URL-10 2017; URL-11 2017; URL-12 2017; URL-13 2017; URL-14 2017)

\begin{tabular}{|c|r|}
\hline İl & $\begin{array}{c}\text { İnşaat/Yıkıntı Atık } \\
\text { Miktarı }\left(\mathbf{~ m}^{\mathbf{3}} \mathbf{)}\right.\end{array}$ \\
\hline İstanbul & $35-40$ milyon \\
\hline Adana & $1.111 .738,46$ \\
\hline Konya & $1.115 .016,27$ \\
\hline Trabzon & 844.173 \\
\hline Malatya & 1.155 .424 \\
\hline Hatay & 706.964 \\
\hline Manisa & $4.180 .000,20$ \\
\hline
\end{tabular}

Tablo 1'de görüldüğü üzere illerin ekonomik ve demografik büyüklüğüne paralel bir biçimde yapısal atık oluştuğu görülmektedir. Sadece İstanbul için onlarca milyon metreküp atık miktarı dikkate alındığında, bu atıkların çevre için büyük tehlike yarattığı, geri dönüşümü ve bertarafı için acil önlem ve uygun yöntemlerin geliştirilmesi gerektiği düşünülmektedir.

Yapısal atıkların Avrupa Birliği ülkelerindeki durumuna bakıldığında ise Eurostat (Avrupa İstatistik Ofisi) 2016 yılı verilerine göre atık üretim miktarında, inşaat faaliyeti sonucu meydana gelen atıklar en büyük değeri oluşturmaktadır (Şekil 4). Yine 2016 yılı verilerine göre ülkelerin toplam atık üretim faaliyetleri içinde en yüksek yapısal atık değerine sahip ülkeler ise Lüksemburg (\%75), Avusturya (\%73), Hollanda (\%70), Fransa (\%69), Malta (\%69), Danimarka (\%58), Almanya (\%55), Birleşik Krallık (\%49) olmuştur (URL-15 2016). İnşaat ve yıkıntı atıklarının miktarının toplam atık miktarına olan oranının değişimi, ülkelerin ekonomik, siyasal ve sosyal faaliyetleriyle ilgili olmakla birlikte, ülkelere göre dağılımda gelişmiş ülkelerin en yüksek değerde yapısal atık ürettiği görülmektedir. Almanya, Fransa ve Birleşik Krallık Avrupa Birliği ülkeleri arasında en çok inşaat ve yıkıntı atığı üreten ülkeler olarak gösterilebilir (Tablo 2).

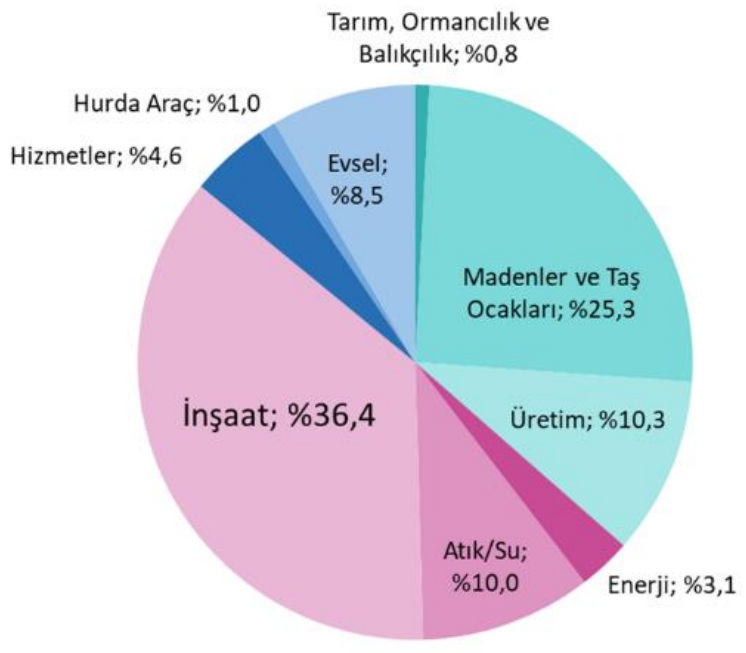

Şekil 4:Avrupa Birliği Ülkelerinin (EU-28) 2016 yılı verilerine göre evsel ve ekonomik faaliyetler sonucu atık üretim miktarının dağılımı (URL-15 2016) 
Tablo 2: 2004-2016 Yılları arasında Avrupa'da inşaat faaliyeti sonucu oluşan atık miktarları (ton) (URL-16 2016)

\begin{tabular}{|c|c|c|c|c|c|}
\hline \multirow{2}{*}{ Ülkeler } & \multicolumn{5}{|c|}{ Yıllara Göre İnşaat ve Yıkım Atık Miktarı (ton) } \\
\hline & $\begin{array}{c}20042006 \\
2008 \\
\end{array}$ & 2010 & 2012 & 2014 & 2016 \\
\hline BE-Belçika & : & $11,487,590$ & $12,893,806$ & $13,629,286$ & $15,818,121$ \\
\hline BG-Bulgaristan & : & 27,109 & 624,332 & 491,341 & 131,45 \\
\hline CZ-Çekya & $:$ & $1,913,208$ & $2,389,602$ & $2,218,403$ & $2,803,748$ \\
\hline DK-Danimarka & $:$ & $1,153,830$ & $2,778,386$ & $3,302,842$ & $3,460,195$ \\
\hline DE-Almanya & $:$ & $76,730,593$ & $77,846,453$ & $78,781,741$ & $86,379,764$ \\
\hline EE-Estonya & $:$ & 203,822 & 307,980 & 318,108 & 485,48 \\
\hline IE-İrlanda & $:$ & $1,176,851$ & 93,691 & 133,312 & 135,61 \\
\hline EL-Yunanistan & $:$ & $1,545,533$ & 601,476 & 355,171 & 126,33 \\
\hline ES-İspanya & $:$ & $10,185,692$ & $25,295,101$ & $5,141,192$ & $12,156,104$ \\
\hline FR-Fransa & $:$ & $65,478,322$ & $62,188,047$ & $61,122,538$ & $60,245,692 *$ \\
\hline HR-Hırvatistan & $:$ & 1,064 & 169,361 & 164,440 & 561,03 \\
\hline IT-İtalya & $:$ & $35,800,652$ & $33,811,563$ & $34,088,306$ & $34,916,038$ \\
\hline CY-Kıbris RK & $:$ & 156,773 & 130,369 & 148,384 & 325,39 \\
\hline \begin{tabular}{|l|} 
LV-Letonya \\
\end{tabular} & $:$ & 18,498 & 4,492 & 452,236 & 107,09 \\
\hline \begin{tabular}{|l|} 
LT-Litvanya \\
\end{tabular} & $:$ & 227,330 & 313,056 & 392,140 & 445,83 \\
\hline LU-Lüksemburg & $:$ & 556,095 & 523,346 & 521,386 & 545,32 \\
\hline HU-Macaristan & $:$ & $2,958,097$ & $2,918,973$ & $1,887,959$ & $1,959,136$ \\
\hline MT-Malta & $:$ & 796,626 & 492,134 & 983,933 & $1,305,819$ \\
\hline NL-Hollanda & $:$ & $20,444,617$ & $19,667,701$ & $19,430,472$ & $19,267,996$ \\
\hline \begin{tabular}{|l|} 
AT-Avusturya \\
\end{tabular} & $:$ & $2,692,451$ & $6,074,851$ & $8,947,894$ & $:$ \\
\hline PL-Polonya & $:$ & $2,764,206$ & $2,599,774$ & $3,316,895$ & $2,471,974$ \\
\hline PT-Portekiz & $:$ & 983,940 & 747,969 & 576,676 & 888,35 \\
\hline RO-Romanya & $:$ & 563,369 & 781,430 & 200,733 & 172,99 \\
\hline \begin{tabular}{|l|} 
SI-Slovenya \\
\end{tabular} & $:$ & 622,431 & 109,807 & 98,923 & 160,94 \\
\hline SK-Slovakya & $:$ & 365,100 & 301,335 & 319,199 & 297,32 \\
\hline FI-Finlandiya & $:$ & $23,100,000$ & $15,681,650$ & 799,808 & $1,315,581$ \\
\hline SE-İsveç & $:$ & 975,000 & 800,000 & $1,600,000$ & $2,552,319$ \\
\hline UK-Birleşik Krallık & $:$ & $56,122,746$ & $52,694,749$ & $58,682,308$ & $63,525,298$ \\
\hline IS-İzlanda & $:$ & 333 & 177 & 20,631 & 28,52 \\
\hline LI-Lihtenştayn & $:$ & 0 & 61,199 & 2,718 & 13 \\
\hline NO-Norveç & $:$ & 903,485 & 772,431 & $1,773,776$ & $2,181,436$ \\
\hline ME-Karadağ & $:$ & $:$ & 0 & 8,446 & 3,3 \\
\hline MK-Makedonya & $:$ & 0 & 0 & 227 & 2 \\
\hline AL-Arnavutluk & $:$ & $:$ & $:$ & $:$ & $:$ \\
\hline RS-Sırbistan & $:$ & 0 & 86,988 & 44,041 & 238,98 \\
\hline TR-Türkiye & $:$ & $:$ & $:$ & $:$ & $:$ \\
\hline BA-Bosna Hersek & $:$ & $:$ & 0 & $:$ & $:$ \\
\hline
\end{tabular}

Yapısal atık miktarı ile ilgili veriler bulunmaması nedeniyle ülkemizin durumunu diğer Avrupa ülkeleri ile karşılaştırmak mümkün olmamaktadır. Ülkemizle ilgili Eurostat atık verileri madencilik, sanayi ve evsel atıkları kapsamaktadır. Ancak son yıllarda görülen gelişmeler ülkemizde de atık kaynaklarının dağılımında yüksek yapısal atık değerini işaret etmektedir. Özellikle 6306 Sayılı Kanunun Uygulama Yönetmeliği’nin, inşaat sektörünü canlandırmaya yönelik olarak revize edilmesi sonucunda artması beklenen kentsel dönüşüm projeleriyle birlikte yıkım ve yapım süreçlerinde hareketlilik yaşanması ve yapısal atık miktarının artması beklenmektedir. Yıllık ortalama 4 milyon ton inşaat ve yıkıntı atığının oluştuğu ülkemizde kentsel dönüşümle bu miktarın iki katına çıkacağı belirtilmektedir (Kotan 2016). Her bir metreküp yapısal atığın ortalama 0,60 metreküpünün geri dönüşebilir içerikte olduğu (Kılıç 2012) düşünüldüğünde kaybedilen malzemenin değeri de tahmin edilebilir. Bu malzemelerin kayba uğramaması ve geri kazanımı için yıkım sahalarında ya da yıkıntı atıklarının depolandığı alanlara geri dönüşüm tesislerinin kurulması önemlidir. Sayıştay Başkanlığı'nın hazırladığı Performans Denetim Raporuna göre; atık dönüşümü yapılmazsa; ihtiyaç duyulacak yeni depolama alanlarının inşası ve işletim ücretlerinin, kentsel yaşam alanlarının içerisinde kalan eski depolama alanlarının tahliye ve taşınma giderlerinin daha yüksek maliyetlere neden olacağı öngörülmüştür. Bu işlemler gerçekleşirken ortaya çıkan hava, su ve toprak kirliliğinin neden olacağı sağlık harcamaları da göz ardı edilmemesi gereken bir diğer unsurdur. Bütün bunlar göz önüne alındığında, atık dönüşümü üzerine yapılacak yatırımın, dört katı kadar getirisi olabileceği sonucunu desteklemektedir (URL-26 2007). 
Bu sonuç, atıkların dönüştürülmesinin ülke ekonomisi ve doğal kaynakların korunmasında ne kadar önemli olduğunu ve 2007 yılında yayınlanan raporun aradan uzun süre geçmesine rağmen düzenlemelerin oluşturulması için ne kadar geç kalındığını göstermektedir.

Yapılan incelemelerde yapısal atıkların ülke ekonomisine kazandırılmasına yönelik düzenlemeler ve uygulamaların yetersiz kaldığı açıkça görülmektedir. Özellikle çevreye olan etkisi, geri dönüştürülebilir malzeme miktarı ve bunun ekonomiye ve inşaat maliyetlerine katkısı düşünüldügüunde yapısal atıkların geri dönüşümünün ne derece önemli olduğu anlaşılabilir. Yapısal atık sorununun çözümlenmesinde geri dönüşümün yanı sıra yapısal atıkların önlenmesi ve azaltılmasına yönelik da tüm dünyada yaygınlaşan yaklaşımlar bulunmaktadır. Bu yaklaşımların temel hedefi atık oluşum kaynaklarını minimalize ederek atık miktarını önlemek ve azaltmaktır. Çalışma; yapısal atıkların geri dönüşüm sürecini yaygınlaştırmak ve geri dönüşüm kazanımını arttırmak amacıyla mevcut düzenlemeleri ve uygulamaları araştırarak yapısal atıkların geri dönüşüm sürecinin hızlandırılmasına katkı sağlamayı ve yapısal atık önleme ve azaltılmasına yönelik olarak yasal düzenlemeleri incelemeyi hedeflemektedir.

\section{Yöntem}

Yapısal atıkların geri dönüşümünü yaygınlaştırmak için yapılması gereken sınıflandırmalar ve uygulamalar kapsamında ülkelerin geliştirdiği mevzuat araştırma sorununu oluşturmaktadır. Çalışmanın amaçları doğrultusunda; yapısal atık oluşum süreci, yapısal atık sınıfları, çevresel etkileri tartışılmaya çalışılmıştır. Çalışmada özellikle yapısal atıkların geri dönüşümü konusunda ülkemize ve gelişmiş ülkelere ait yürürlükteki mevzuat incelenerek yapısal atıkların geri dönüşümü konusunda ülkelerin yaklaşımları ve tutumları belirlenmek istenmiştir. Bu amaçla Avrupa Birliği Atık Çerçeve Direktifi ile birlikte Amerika Birleşik Devletleri, Japonya, Hong Kong, Çin gibi ülkelerin yapısal atık yönetimi yaklaşımları incelenmiştir. Çalışmanın sonunda yapılan değerlendirmeler ışığında yapısal atık yönetimi konusunda ülkemizin durumu tespit edilmek istenmiş, gelecekte neler yapılabileceği konusunda öneriler geliştirilmesi hedeflenmiştir.

\section{Yapısal Atık Oluşumu, Çevresel Etkileri ve Geri Dönüşümü}

Yapısal atıklar şehirde oluşan en ağır ve en büyük hacimli atıklar arasındadır. Kentsel faaliyetler sonucunda üretilen atıkların yaklaşık \%25-\%30'unu oluşturan (Öztürk 2005) yapısal atıklar, yapı ömrü boyunca çeşitli aşamalarda ortaya çıkar. Bu bakımdan yapısal atık oluşum sebepleri ve miktarları aşamalara göre farklılık göstermektedir. Bu aşamalar bir bakıma yapısal atıkların kaynağını da işaret eder niteliktedir. Wu vd. (2014)'ne göre yapı ömrü boyunca atıklar şu şekilde ortaya çıkar;

a. Uygulama aşamasında oluşan atıklar: Bu atıklar yapım süreci esnasında yapılan hafriyatla birlikte, yapımda kullanılan malzemenin işlenmesi sırasında ortaya çıkan artıklar ve kayıplar ile ambalaj atıklarından oluşur.

b. Kullanım aşamasında oluşan atıklar: Bu atıklar yapı kullanımı süresince ortaya çıkan eskime, bozulma, teknik yetersizlik, yeni kullanıma adapte etme gibi nedenlerle gerek görülen yenileme, iyileştirme ve güçlendirme işlemlerini kapsayan faaliyetler sonucunda oluşur.

c. Yapı ömrünü tamamlaması sonucu oluşan atıklar: Bu atıklar yapının ömrünü tamamlamasıyla birlikte yapının çeşitli yöntemlerle yıkılması sonucu ortaya çıkan atıklardır.

Yapısal atıkların neler olduğu inşaat yapım tekniğine, proje büyüklüğüne, malzeme cinsine ve malzeme depolama yöntemine, oluşabilecek teknik aksaklıklara ve sahadaki insan faktörüne bağlı olarak değişim gösterebilmektedir (Wu vd. 2014). Ancak günümüzde kullanılan yaygın yapım teknolojileri ve malzemeleri dikkate alındığında içeriğin beton, agrega, sıva, jips, tuğla, tahta, briket, cam, metal parçası (çelik, demir, alüminyum, pirinç, bakır), alçı, kiremit, plastik, elektrik malzemeleri ve asfalt gibi malzemelerden oluştuğu söylenebilir (Öztürk 2005).

Hafriyat Toprağı, İnşaat ve Yıkıntı Atıklarının Kontrolü Yönetmeliği'ne göre yapısal atıkların sınıflandırıldığı görülmektedir. Buna göre;

a. Hafriyat toprağı

b. Yol yıkıntı atıkları

c. Yikıntı atıkları

d. Karışık yıkıntılar olarak gruplara ayrılmıştır.

Yapısal atıklar çevre kirliliğinin önemli faktörlerinden biridir. Artan nüfusla beraber artan inşaat hızına bağlı olarak çoğalan yapısal atıklar sebebiyle beliren çevre kirliliği de doğal olarak artış göstermektedir. Atıkların çevresel etkilerini azaltmak için bir dizi önlemler alınması gerekmektedir. Özellikle insan eliyle üretimi söz konusu olmayan ve yapım sürecinde hafriyat esnasında ortaya çıkan bitkisel toprağın geri kazanımı ve yeniden kullanımı oldukça önemlidir. Toprak gelişi güzel yerlere dökülmek yerine uygun alanlarda peyzaj düzenlemelerinde kullanılmalıdır.

Bunlara ek olarak yapım sürecinde kullanılacak kum, çakıl, çimento gibi malzemelerin gelişi güzel yerlerde depolanması sonucu ortaya çıkabilecek çevre kirliliğinin de önlenmesi gereklidir. Yapının yıkımı sırasında oluşabilecek kirlilik düzeyleri şu şekilde sıralanabilir; 
- Hava kirliliği,

- Yeraltı suyu kirliliği,

- Arazi kirliliği,

- Toprak kirliliği,

- Diğer kirlilikler (Öztürk 2005).

Oluşabilecek çevresel kirlilikleri önlemek ve doğal kaynakların tüketilmesinin azaltabilmek için geri dönüşüm kaçınılmazdır. Dönüştürmediğimiz yapısal atıkların doğada yok olma süreleri, demir için 200-300 yıl, cam için 40004500 yıl, poliüretan köpük için 1000 yıl, alüminyum için 100-300 yıl ve strafor malzemeler için +2 milyon yıl olduğu tahmin edilmektedir (URL-17 2018). Oldukça büyük miktarı geri dönüşebilir nitelikte olan yapısal atıkların geri dönüştürülmesi, yapım ve yıkım faaliyeti sonuçlarıyla oluşabilecek kirlilik ve atık potansiyelini, çevresel ve ekonomik bir problem olmaktan çıkararak, geniş etkileri olan kazanımlara dönüştürülmesine olanak tanımaktadır. Gelişmiş ülkeler arasında Hollanda \%90, Avusturalya \%87, Danimarka \%82 oranında yapısal atıkların dönüşümünü sağlarken (Arslan vd. 2012), yeterli veri bulunmamakla birlikte, ülkemizde geri dönüşüm oranlarının çok düşük düzeylerde olduğu bilinmektedir. Bunun en önemli sebebinin ülkemizde geçerli bir atık yönetimi altyapısının olmamasının yanında mevzuat ve uygulamalardaki eksiklikler olduğu düşünülmektedir. Sonuç olarak atıklarla birlikte her yıl doğal kaynaklarımızın tükenmesinin yanında milyarlarca liralık milli servet de boşa gitmektedir. Bu durumun kısa vadede ekonomik ve sosyal etkileri çabucak gözlenebilir olmakla birlikte, görece uzun vadede çevrenin kendini yenileyebilme kapasitesi yok edilmektedir.

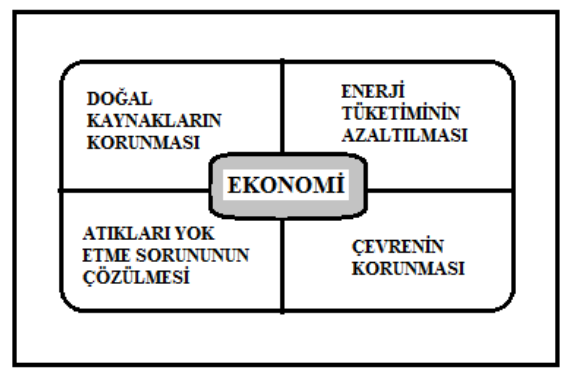

Şekil 5: Yapısal atıkların geri dönüştürülmesinin yararları (Behera vd. 2014)

Behera vd. (2014)'ne göre yapısal atıkların geri dönüştürülmesi ile doğal kaynakları korunması, enerji tüketiminin azaltılması, atıkları yok etme sorununun çözülmesi ve çevrenin korunması sağlanarak ekonomiyi desteklediği söylenebilir (Şekil 5). Ülkemizde yapısal atıklar çoğunlukla; inşaat yıkım aşaması öncesi sökülen doğramalar,vitrifiyeler,mutfak dolapları, mutfak tezgahları ve yer kaplamaları gibi yapı elemanlarının olduğu gibi yeniden kullanılmasıveya betonarme inşaatların yıkımı sonrası demirlerin istiflenip demir-çelik fabrikalarınageri dönüşüm için gönderilerek değerlendirilmektedir (Şekil 6).

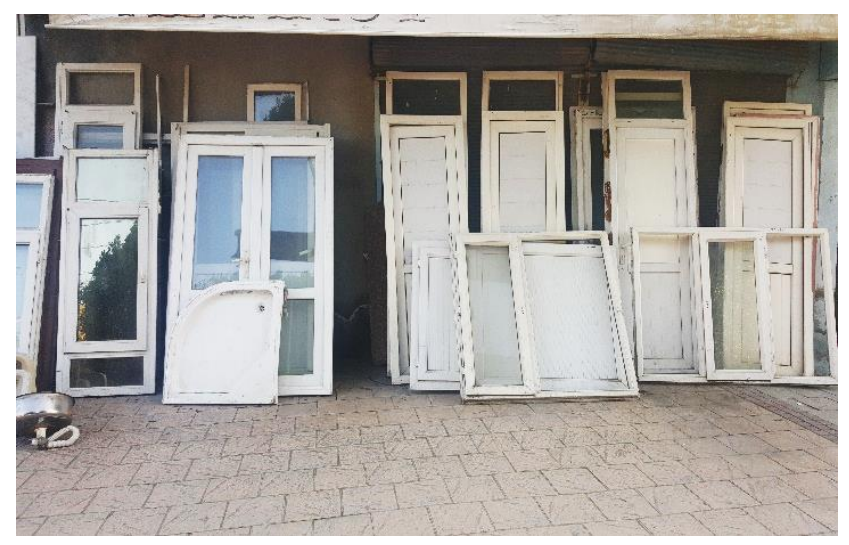

a) Çıkma kapı ve pencere depolama ve satış alanı (Foto: Ceyda Buzkan)

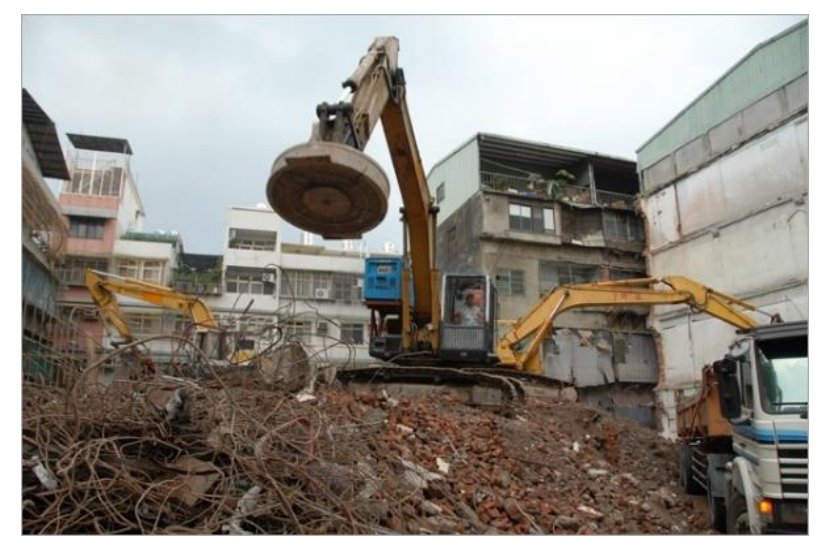

b) Yıkım sonrası atık demirin toplanması (URL-18 2018)

\section{Şekil 6: Ülkemizde yapısal atıkların yeniden kullanımı ve geri dönüşüm için ayırımı}

Avrupa'da yapısal atık geri dönüşümünü en çok gerçekleştiren ülkelerin başında Hollanda gelmektedir. Özellikle geri dönüştürülmüş yapı malzemesi üretimi ve bu malzemelerden inşa edilen yapı üretimi yaygın uygulamalar arasındadır. 
Şekil 7'de örnek verilen konut yapısı 15000 kg yapısal atık malzemenin yukarı yönlü geri dönüşümü (upcycle) sağlanarak üretilen tuğlalardan inşa edilmiştir. Yapımda kullanılan tuğlaların hammaddesinde $\% 60-\% 70$ oranında yapısal atık malzeme kullanılmıştır (URL-19 2019).
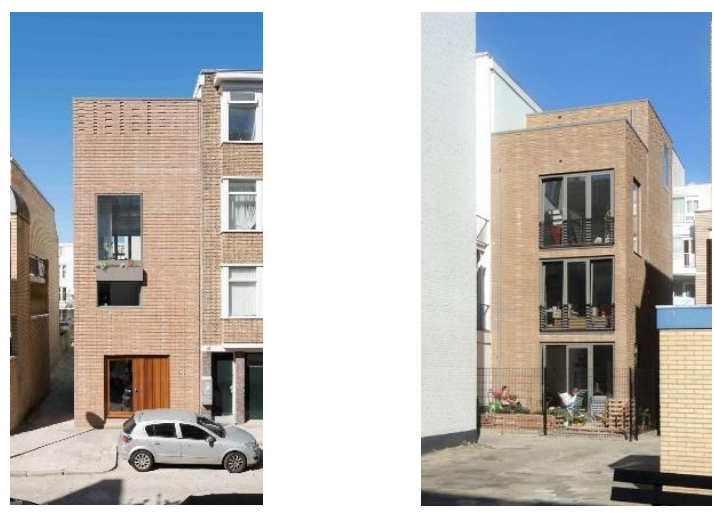

Şekil 7: Hollanda Rotterdam'da atık malzemelerden üretilmiş tuğlalarla inşa edilmiş konut (URL-19 2019)

Yapısal atıkların arzu edilen düzeyde geri dönüşümünün sağlanabilmesi için alanda yapının yıkımıyla birlikte başlayan yapısal atık oluşum sürecinin de planlanması gerekmektedir. Yapının yıkımı esnasında hangi aşamada hangi yaklaşım ve yöntemle dönüştürülebilecek malzeme ve maddelerin elde edilebileceği planlanarak geri dönüşüm sürecinin daha etkin bir şekilde yönetilebileceği düşünülmektedir. Bu noktada vurgulanması gereken diğer bir konu da yapısal atığı oluşturan yapı tipi, yapının üretim şekli ve malzemesi, strüktür biçimi ve yapının kullanım amacıdır. Her ne kadar yapılar yapı bileşenleri bakımından benzerlik gösterse de yapı malzemesi ve yapı üretim şeklinin yapısal atık oluşumunda belirleyici olduğu açıktır. Dolayısıyla etkin bir dönüşüm süreci için ilgili yasal düzenlemelerde bu konunun da dikkate alınması gerekmektedir.

\section{Gelişmiş Ülkelerde ve Türkiye'deki Atık Yönetimi Mevzuatı}

Atık yönetimi; atıkların çevre ve insan sağlığına zararlı etkisini önlemek amacıyla çeşitli metotların belirli hedefler doğrultusunda kontrollü olarak gerçekleştirilmesi olarak tanımlanabilir. Çevre ve insan sağlı̆̆ için, atıkların oluşumundan bertarafına kadar yönetiminin sistematik bir şekilde sağlanması gerekmektedir. Dünyada oluşan atıkların yönetiminin verimli bir şekilde değerlendirilmesi için birtakım kurallar belirlenmiştir. Bu kapsamda Avrupa Birliği tarafından Atık Çerçeve Direktifi (2008/98/EC) ile doğal kaynak kullanımının en aza indirilmesi amacıyla, atık oluşumunun azaltılması öncelikli olarak kabul edilerek, atıkların yeniden kullanımı, geri dönüşümü, geri kazanımı gibi yollarla atık yönetimi konusunda belirli bir hiyerarşi oluşturulmuştur. Ancak bu süreç içinde en etkili ve öncelikli adımın atık oluşumunun engellenmesi, en son tercih edilecek adımın ise bertaraf edilmesi olduğu belirtilmektedir (Şekil 8).

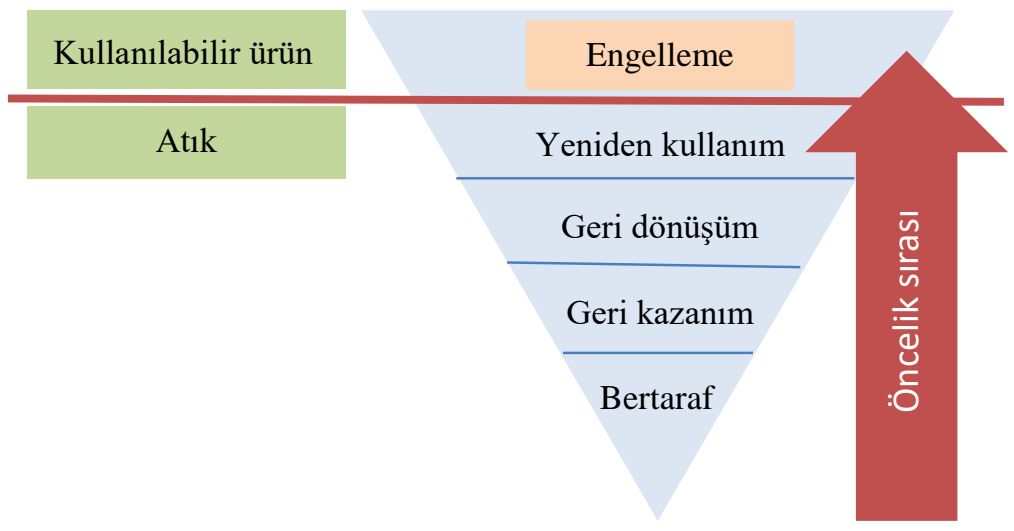

Şekil 8: Atık Yönetimi Hiyerarşisi (URL-20 2019) 


\subsection{AB Çevre Politikası ve Direktifleri}

Temel hedefi üye ülkelerinin ekonomik kalkınmalarını ve dayanışmalarını sağlamak olan ve aynı zamanda çevreyi en üst seviyede korumayı hedefleyen Avrupa Birliği (AB) örgütü çevre politikaları konusunda birçok çalışma yürütmektedir. 01.12.2009 tarihinde yürürlüğe giren Lizbon Antlaşmasıyla kirliliği ortadan kaldırmak, doğal kaynakları ekolojik dengeye zarar vermeden kullanarak sürdürülebilir kalkınma sağlamak, çevreye zarar verebilecek her türlü eylemi kaynağında önlemeye çalışmak AB'nin çevre politikasının hedefini oluşturmaktadır. AB'nin çevre politikasının temel ilkeleri, "kirleten öder", "bütünleyicilik (diğer politikalarla birliktelik)", "yüksek seviyede koruma", "kaynakta önleme", ve "ihtiyat önleme (çevreye olumsuz etkileri olabilecek bir eylemin bilimsel ispatını beklemeden önlem alınması)" şeklinde sıralanabilir. AB çevre politikasının gelişiminde, 1973 yılında ilki yayınlanan ve yedincisinin 2020 yılına kadar geçerli olacağı düşünülen çevre eylem planları oldukça etkili olmuştur. Bu planlar herhangi bir hukuki yaptırıma sahip olmamakla birlikte, üye ülkelerin ve üye ülke nezdindeki çalışma gruplarının eş zamanlı çalışmalarını önermek amacıyla oluşturulmaktadır. "Living Well, Within The Limits of Our Planet" (Gezegenin Sınırları İçinde, Daha İyi Yaşamak) sloganıyla 17 Ocak 2014'te yürürlüğe giren 31 Aralık 2020 tarihine kadar geçerli olması öngörülen 7. Çevre Eylem Planı kapsamında, doğayı korumak ve ekolojik direnci güçlendirmek, kaynak verimliliği sağlamak, düşük karbonlu büyümeyi artırmak ve kirlilik, kimyasal maddeler ve iklim değişikliğinin etkileri ile bağlantılı insan sağlığına ve refahına yönelik tehditleri azaltmak için öncelikli çalışma alanları belirlemiştir (EU 2019). Bu kapsamda belirlenen öncelikli çalışma alanları şu şekildedir (EU 2019):

a) Çevre mevzuatına ilişkin uygulamaların geliştirilmesi, bilgi ve deneyimin artırılması,

b) Çevre ve iklim politikaları kapsamında gerekli yatırımın sağlanması,

c) Şehirlerin etkin sürdürülebilirliğinin desteklenmesi,

d) Birliğin uluslararası boyutta çevre ve iklim sorunları konusunda faaliyetlerinin güçlendirilmesi.

Atık Önleme ve Geri Kazanımı stratejisi atık yönetimindeki sorunların ve öncelikli konuların tanımlanmasında güncel gelişmelere paralel olarak bir ilerleme kaydetmek amacıyla 2006 yılında Atık Çerçeve Direktifi'ni revize etmiştir. Revizyon ile AB atık yönetimi politikasında atık; sadece kaynağında önlenmesi tavsiye edilen bir kirletici unsur olmayıp uygun metotlarla geri kazanımı ve geri dönüşümü değerlendirilebilecek bir kaynak olarak ele alınmıştır. Atık Çerçeve Yönergesi (2006/12/EC sayılı Yönerge) atığın önlenmesi, yeniden kullanımı, geri dönüşümü ve geri kazanımı, yakma ve son olarak düzenli depolama gibi yöntemler ile atığın bertaraf edilmesi anlayışına odaklanmıştır. AB, çevre koruma hedefleri doğrultusunda yetersiz bulunan bu direktifi düzenleyerek kapsamlı bir atık politikası oluşturmayı hedeflemiştir. Bu bağlamda AB Komisyonu tarafından yayımlanan ve yapısal atık yönetimini de kapsayan, katı atık yönetimi alanındaki geçerli düzenleme 2008/98/AT sayılı Atık Çerçeve Direktifidir. AB'nin 2008/98/EC sayılı Atık Çerçeve Direktifi'nde Avrupa toplumunun kaynak verimliliğinden daha fazla yararlanabilmesini sağlanması ve bunun için geri dönüşüm seviyelerinin yükseltilmesi gerektiği ifade edilmektedir. AB üyesi devletlerin 2014 yılında yapısal atıkların \%88'ini dönüştürebildiği, bu oranın 2010 verilerine göre \%10 oranında arttı̆̆ belirtilmektedir. 28 üye ülkeden Malta, İrlanda, Hollanda ve Lüksemburg \%95'in üzerinde geri dönüşüm oranına sahiptir. Bu kapsamda 2020 y1lına dek üye ülkelerin tümünün, tehlikeli olmayan yapısal atıkların ağırlıkça \%70 oranında dönüşümünü sağlaması hedeflenmektedir (URL-21 2018), (Şekil 9).

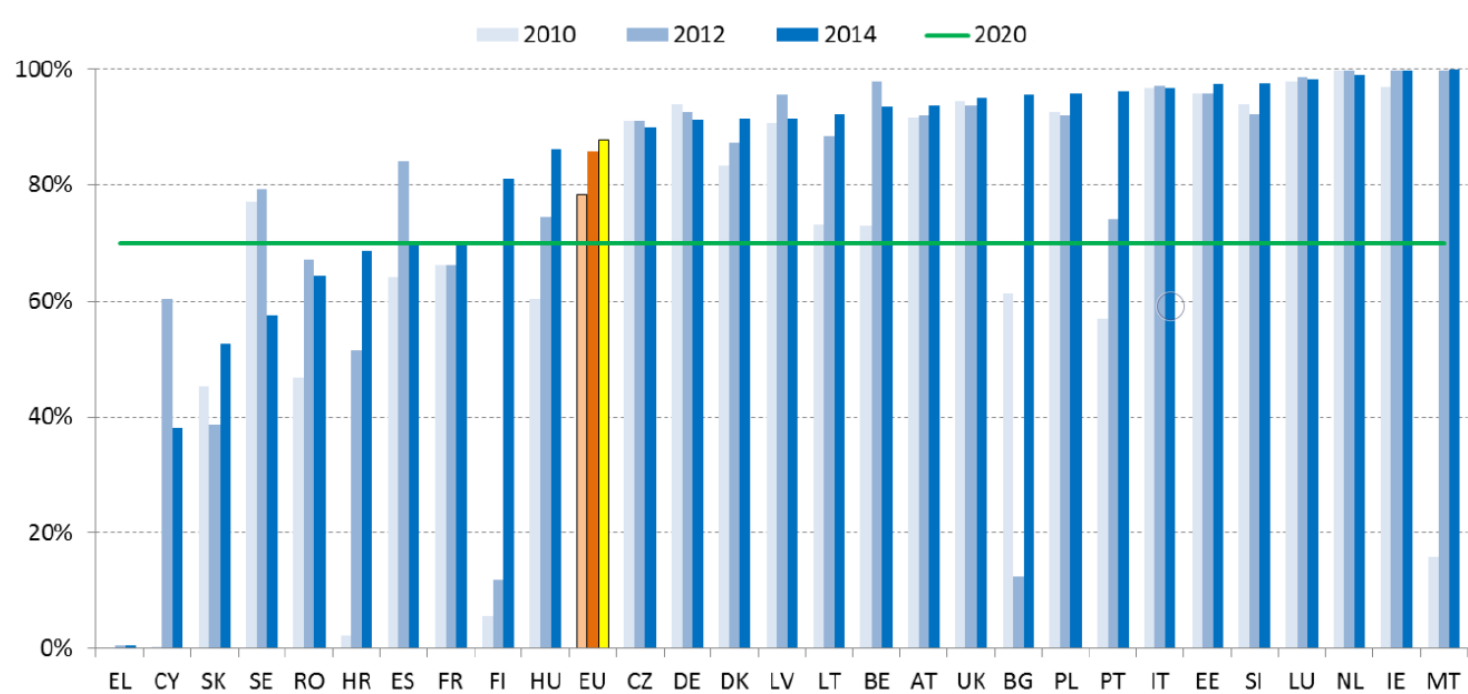

Şekil 9: 2010-2014 Yılları arasında Avrupa'da inşaat ve yıkıntı atıklarının geri dönüşüm oranlarının değişimi (URL-21 2018) 
Avrupa Birliği bünyesinde bulunan çoğu ülke çevre politikası hedeflerine ulaşmak için yasal düzenlemeler yardımıyla geri dönüşüm oranlarını arttırmaktadırlar. Atıklar için uygulanan depolama ve bertaraf etme gibi durumlarda ödenecek yüksek vergi oranlarının da bu durumu desteklediği düşünülmektedir. Örneğin İngiltere hükümeti 2008 y1lı Haziran ayında yayınladığı "Sürdürülebilir Yapı Stratejisi”nde yeni yapıların inşasında ve kullanımında karbon emisyonunu ve kaynak tüketimini azaltmaya odaklanmıştır. Stratejiye göre 2020 yılına dek yapısal atıkların atık sahalarında depolanarak bertaraf edilmesinin tamamen sonlandırılması hedeflenmektedir. Bu kapsamda 2011 yılından itibaren ton başına $56 £$ Atık Depolama Vergisi uygulamaya konulmuş, proje büyüklüğü $300.000 £$ değerini aşan uygulamalar için Yerleşim Atık Yönetimi Planı hazırlanması zorunlu hale getirilmiştir (Osmani 2012).

\subsection{Gelişmiş Ülkelerde Atık Yönetimi}

Japonya'da, Atık yönetiminin yasal reformu, geleneksel eylem tarzına getirilen önemli ve köklü değişikliklerle ve bireysel araçlarla gelişmiştir.2011 yılı verilerine göre 75,4 milyon ton ağırlığında ve toplam atık miktarının \%20'si oranında büyüklüğe sahip olan Japonya'da atıkların yönetimiyle ilgili gelişmeler üç evrede özetlenebilir. 1970'lerde Atık Yönetimi Yasası (Waste Management Act) ile başlayan ilk evrede sanayi ve belediye atı̆̆ı ayrımı yapılmış, belediyelere atık yönetimi konusunda sorumluluklar verilmiştir. 1990'larla başlayan ikinci evrede ise artan sanayileşme, atık yönetiminin yetersizliği, kontrolsüz atık depolama faaliyetlerinin artması, yeni bir politika arayışına neden olmuştur. Böylece 1991 yılında Atık Yönetimi Yasası revize edilerek, atık üretiminin azaltılması ve atıkların geri dönüşümü konuları yasaya eklenmiştir. 1992 yılında ise yasadışı atık dökmeye karşı ağır yaptırımlar getiren düzenlemeler yapılmıştır. Üçüncü evre ise 2000 yılında çıkarılan ve geri dönüşüm temelli bir toplum oluşturmak hedefini taşıyan Geri Dönüşüm Toplum Yasası (Recycled Society Act) ile başlar (URL-22 2014; Gao 2018).

1991'de revize edilen Atık Yönetimi Yasası ile atığın faydalı olma durumunu ifade etmek için atık kavramı yerine "yan ürün” kavramı geliştirilmiştir. Yan ürünü işlemek için kullanılan tesisleri tanımlamak için de "geri dönüşüm tesisi” kavramı kullanılmıştır. Yapılan düzenlemelerle yükleniciler çevre dostu ürünler almakla yükümlü tutmuş, kamusal işlerde kullanılacak malzemelerin geri dönüştürülmüş içerikli olması konusunda katı kurallar hazırlanmıştır. Ayrıca İnşaat Yan Ürünleri Kılavuzu hazırlanmış, yapısal atık endüstrisinin yan ürünleri kum taşı, beton blok, bitümlü beton blok, ahşap ve yapım agregası olarak belirlenmiştir. Bu kılavuz yan ürünlerin kullanımında ve taşınmasında kamu ve özel sektörde görev yapan yüklenicilerin sorumluluklarını tanımlamıştır (Gao 2018).

2000 yılında ise İnşaat Malzemeleri Geri Dönüşüm Yasası (Construction Materials Recycling Act) ile yapısal atıkların inşaat ya da yıkım alanında sınıflanması ve ayrıştırılmasıyla birlikte belirli yapısal atıkların dönüşümü konusunda yasal düzenlemeler yapılmıştır. 2001 yılında yürürlüğe giren Yeşil Satınalma Yasası (Green Purchasing Act) ile hükümetin kamusal kullanıma ait yapıların inşasında çevre dostu malzeme ve yapısal atıklardan geri dönüştürülmüş malzeme kullanımı belli koşullar altında zorunlu hale getirilmiştir (Gao 2018). Japonya' da yapısal atıklar konusundaki çalışmaların 3R (reduce, reuse, recycle) prensibi üzerine kurgulandığı ve yapılan düzenlemelerde özel sektörün ve kamunun sorumluluklarının tanımlandığı görülmektedir.

Hong Kong'da yapısal atıkların yönetimi ve azaltılmasıyla ilgili çalışmalar 2003 yılında uygulamaya konulan atık yönetimi planı ile başlamaktadır. Yine 3R prensibine dayanan Atık Azaltılması Çerçeve Planında (Waste Reduction Framework Plan) (Gao 2018):

- Azaltılacak atık türleri tanımlanır. Çevreye zararlı, daha büyük hacimli, geri dönüşüm potansiyeli yüksek atıklara öncelik verilir.

- Atık azaltma hedefleri belirlenir. Tanımlanan her atık tipi için atık azaltma ve geri dönüşüm oranı belirlenir.

- Atık azaltma programı yapılır. Her bir atık türü için atık azaltmaya yönelik süreç ve faaliyetleri gösteren kılavuzlar hazırlanır.

- Atık imha prosedürleri tanımlanır. Her bir atık tipi için uygun atık imha yöntemleri tanımlanır.

Sanayi atıklarını ve çevresel zararlarını azaltmaya yönelik olan ISO14000 standartlarını uygulayan Hong Kong’ta 2017 yılı verilerine göre 304 adet inşaat firması sertifika sahibidir (URL-23 2017).Ayrıca kirleten öder prensibi kabul edilen ülkede belirlenmiş bir depolama sahasına, her bir ton zararlı olmayan yapısal atık dökümü $27 \$$ olarak ücretlendirilmektedir.

Çin de geri dönüşüm konusunda 3R prensibini uygulamaktadır. Ulusal ve bölgesel düzeyde düzenlemelerle atık yönetiminin yapıldığı Çin’de ulusal düzeyde ilk yasal düzenlemeler 1995 yılında çıkarılan Kent Görünümü ve Çevre Sağlığı Kontrolü Yönetmeliği ile başlar. 2000’li yıllarda yürürlüğe giren yasa ve yönetmeliklerle atık kontrolünde paydaşların sorumlulukları tanımlanmış, yapısal atıkların geri dönüşümünde finansal destekler belirlenmiş, yapısal atıkların taşınması, depolanması ve kullanımı için rehberler hazırlanmıştır (Huang vd. 2018). Ülke genelinde yapılan çalışmalar üretilen katı atıkların resmi kayıtlara göre \%30-40'ının yapısal atıklardan oluştuğunu, yapısal atıkların geri dönüşümünün ise \%5'in altında olduğunu göstermektedir (Huang vd. 2018). Geri dönüştürülen malzemelerin daha çok ekonomik değeri yüksek olan bakır ve çelik olduğu, beton ağırlıklı atıkların ise atık sahalarına dökülerek bertaraf edildiği belirtilmektedir (Zhao vd. 2008). Her ne kadar geçerli mevzuat bulunsa da Çin'de yapısal atıkların geri dönüşüm oranının çok düşük olduğu görülmektedir. Bu durum pek çok nedene bağlanabilir olsa da esas nedenin dönüşümün bir ekonomi modeliyle desteklenmemesi olduğu düşünülmektedir. 
Özellikle Avrupa topluluğu ülkelerinin dönüşüm oranlarıyla birlikte dönüşüm stratejileri incelendiğinde, bu ülkelerin dönüşüm modellerinin sosyal ve çevresel kazanımlar yanında ekonomik hedeflerinin de olduğu görülmektedir.

Amerika Birleşik Devletleri'nde ise Çevre Koruma Ajansı (Environmental Protection Agency), atık yönetimini 4R (reduce, reuse, recycle, rebuy) ile tanımlamıştır. Diğer ülkelerden farklı olarak rebuy-yeniden satın al prensibi ise kullanıcıların satın alma alışkanlıklarını değiştirerek biyolojik temelli ve geri dönüştürülmüş ürünleri tercihe etmeye teşvik eder (EPA 2019). Atık azaltma prensibini, kaynağında önleme olarak ele alan atık yönetiminde, yapıyı yıkmak yerine kullanmak hedeflenerek, yapının ömrünü uzatabilmek için optimum șekilde ve yeni kullanımlara kolay adapte olabilecek biçimde tasarlamaya vurgu yapılmaktadır. Bu kapsamda EPA'nın pilot çalışmaları bulunmaktadır. Yıkım sonrasında geri dönüşümlü malzemelerin sağlanmasında kayıp olmaması amacıyla EPA yıkım rehberleri de hazırlamıştır. Bu rehberler atık tiplerine göre yıkım ve sökümün nasıl yapılacağını ve elde edilen malzemenin nasıl kullanılabileceğini göstermektedir.

Ayrıca dünya genelinde yapıların inşa edilirken ve kullanılırken çevre olan etkilerini en aza indirmek amacıyla çeşitli bina sertifika sistemleri geliştirilmiş̧ir. Amerika'da LEED (Leadership in Energy and Environmental Design-Enerji ve Çevresel Tasarımda Liderlik), Kanada'da Green Globes, Kaliforniya'da Green Building Code, Brezilya'da AQUA, Avrupa'da BREEAM (Building Research Establishment-Environmental Assessment Method), Almanya'da DGNB (Deuthche Gesellschaft für Nachhaltige Bauen), Japonya'da CASBEE (Comprehensive Assessment System for Built Environment Efficiency) gibi sertifikalar bulunmaktadır. Bu sertifikalar; yeşil bina tasarımının ve üretiminin yaygınlaştırılmasını, çevresel sürdürülebilirliği ve kaynakların korunmasını sağlamayı amaçlar. Sözü edilen sertifikalama sistemlerinde yapılan derecelendirmede kaynakların verimli kullanılmasına, sahada oluşan atı̆̆ın kontrolüne, strüktürün yeniden kullanılabilir, malzemelerin ise dönüştürülebilir olmasına önem verilmektedir. Bu kapsamda sertifikalandırma sistemleri, yapıların çevreye duyarlı olmasını sağlamak ve kaynak kullanımını azaltmak için yapısal atıkların değerlendirilmesini destekleyici bir sistem olarak tanımlanabilir.

\subsection{Türkiye’de Yapısal Atık Yönetimi, Yönetmelikler ve Eylem Planı}

Ülkemizde kentsel kalkınma faaliyeti sanayileşme ve şehirleşme yönündeki çalışmalar zemininde esas olarak inşaat faaliyetlerine dayanmaktadır. Bu kapsamda gerçekleşen, konut, bina, köprü, yol ve benzeri alt ve üst yapıların yapım işlerinin yanı sıra, mevcut alt ve üst yapıların tamiratı, tadilatı, yenilenmesi ve yıkımı sırasında da çok büyük miktarda hafriyat toprağı ile inşaat ve yıkıntı atıkları oluşmaktadır. İnşaat ve yıkıntı atıklarının oluşumunda başta deprem olmak üzere çeşitli doğal afetlerin de birer faktör olduğu söylenebilir. Afetlerin etkisiyle yapıların yıkılması ve hasar görmesi sonucunda yapısal atık meydana gelmektedir. Bu atıkların gelişigüzel şekilde alıcı ortama verilmesi ise çevre kirliliğine neden olmakta, söz konusu, atıkların belirli bir sistem içinde yönetim esaslarının belirlenmesi zorunluluğu ortaya çıkmaktadır (Güler 2018).

Yapım esnasında, yıkım sırasında ve sonrasında oluşan hafriyat toprağı, inşaat ve yıkıntı atıklarının yönetimine ilişkin olarak ise 18.03.2004 tarihinde 25406 sayılı Resmi Gazete'de yayınlanan yönetmelik yürürlüğe girmiştir. Hafriyat, İnşaat ve Yıkıntı Atıklarının Kontrolü Yönetmeliği’nin yapısal atıkların kontrolü konusunda getirdiği ilkeler şunlardır; (HIYAKY 2004).

- Hafriyat toprağı ile inşaat-yıkıntı atıklarının kaynağında en aza indirilmesi

- Hafriyat toprağı ile inşaat-yıkıntı atıklarının geri kazanılması ve özellikle alt yapı malzemesi olarak yeniden değerlendirilmesi

- Hafriyat toprağı ile inşaat-yıkıntı atıklarının karıştırılmaması,

- Sağlıklı bir geri kazanım ve bertaraf sisteminin oluşturulması için atıkları kaynağında ayrılmasının sağlanması ve bu kapsamda seçici yıkımın yapılması.

Halen yürürlükte olan bu yönetmeliğin genel esasları şu şekildedir;

a) Atıkların kaynağında en aza indirilmesi esastır.

b) Hafriyat toprağı ile inşaat/yıkıntı atıklarının geri kazanılması ve özellikle alt yapı malzemesi olarak yeniden değerlendirilmesi esastır.

c) Hafriyat toprağı ile inşaat/yıkıntı atıklarının karıştırılmaması esastır.

d) Sağlıklı bir geri kazanım ve bertaraf sisteminin yapılandırılabilmesi için atıkların kaynağında ayrılması ve "seçici yıkım" esastır (HIIYAKY 2004).

Çevre ve Şehircilik Bakanlığı'nın yetki ve sorumluluğuna devredilmesinin ardından bakanlıkça hafriyat ve yıkıntı atıklarının kontrolü konusunda yeni bir çalışma başlatılmıştır. En son gelinen noktada "Yıkım İşlemleri ile Hafriyat Toprağı, İnşaat ve Yıkıntı Atıklarının Kontrolü Yönetmeliği’" adı altında hazırlanan taslak metin 2017 yılında görüşe açılmıştır. Ancak bu yönetmelik taslağı ile ilgili çalışmalar henüz sonuçlanmamıştır.

19/11/2008 tarihli ve 2008/98/AT sayılı atık hakkında Avrupa Parlamentosu ve Konsey Direktifi, 3/5/200 tarihli ve 2000/532/AT sayılı Atık Listesi Oluşturulması Hakkında Komisyon Kararı dikkate alınarak Avrupa Birliği mevzuatına uyum çerçevesinde hazırlanan ve 02.04.2015 tarihinde yürürlüğe giren Ulusal Atık Yönetimi Yönetmeliği’nin bazı genel ilkeleri şunlardır; 
- Doğal kaynakların olabildiğince az kullanıldığı temiz teknolojilerin geliştirilmesi ve kullanılması,

- Üretim, kullanım, geri kazanım veya bertaraf aşamalarında çevre ve insan sağlığına en az zarar verecek şekilde ürünlerin tasarlanması, pazarlanması,

- Daha dayanıklı, yeniden kullanılabilir ve geri dönüştürülebilir ürünlere odaklanan teknolojiler ile atık üretimine ve atık içerisinde bulunan zararlı maddelere yönelik, ürün çevresel tasarım yaklaşımının oluşturulması, suretiyle önlenmesi ve azaltılması esastır.

- Doğal kaynak ve enerji kullanımının azaltılmasına yönelik olarak geri kazanılmış ürünlerin kullanımının özendirilmesi esastır.

- Atıkların kaynağında ayrı toplanması, geçici depolanması, taşınması ve işlenmesi sırasında su, hava, toprak, bitki, hayvan ve insanlar için risk yaratmayacak, gürültü, titreşim ve koku yoluyla rahatsızlığa neden olmayacak, doğal çevrenin olumsuz etkilenmesini önleyecek ve böylece çevre ve insan sağlığına zarar vermeyecek yöntem ve işlemlerin kullanılması esastır.

- Bakanlık, atık işleme tesislerine yönelik temiz üretim teknolojilerinin kullanımını sağlayacak mekanizmaları olușturur.

- Farklı türdeki atıkların kaynağında/üretildikleri yerde diğer atıklarla karıştırılmaksızın, sınıflandırılarak ayrı toplanmasi esastir.

- Atıkların, Bakanlıkça belirlenen esaslar dışında farklı bir yöntemle toplanması ve ayrılması yasaktır.

- Atıkların toprağa, denizlere, göllere, akarsulara ve benzeri alıcı ortamlara dökülmesi, doğrudan dolgu yapılması ve depolanmasi suretiyle çevrenin kirletilmesi yasaktır (AYY 2015).

Ulusal Atık Yönetimi ve Eylem Planı (UAYP) 2016-2023 kapsamında hafriyat ile çıkan bitkisel toprakla inşaat/yıkıntı atıklarının karıştırılmamasına, atıkların kaynağında en aza indirilmesine, geri kazanılmasına ve özellikle alt yapı malzemesi olarak yeniden değerlendirilmesine önemle vurgu yapılmaktadır. Geçerli bir geri kazanım ve bertaraf sisteminin oluşturulması için atıkların oluşumu sırasında kaynağında ayrılması ve bu amaçla "seçici yıkım" yapılması yine üzerinde önemle durulan diğer konulardır. Eylem planında hafriyat toprağının nasıl kullanılacağı ve ne şekilde depolanacağı da aktarılmaktadır. Benzer şekilde asfalt atıklarının geri kazanım tesislerinde yeniden işlenerek aşağı yönlü dönüşüm sonucu elde edilen ürünün yoğunluğu daha az olan yollarda dolgu malzemesi olarak kullanılması ya da tekrar asfalt üretim tesislerinde değerlendirilmesinin mümkün olduğuna işaret edilmektedir. Ancak sunulan öneriler ve yaklaşımlar oldukça karışık içeriğe sahip olan inşaat ve yıkıntı atıklarının geri dönüşümü konusunda oldukça sınırlı ve yüzeysel kalmaktadır.

UAYP 2014 anketine hafriyat toprağı, inşaat ve yıkıntı atıkları yönetimi ile ilgili oldukça sınırlı veri girişi yapılmıştır. Anket sonuçlarına göre hafriyat toprağı yönetimi kapsamındaki çalışmaların büyük bir kısmının İstanbul, Bursa, Sakarya, Kocaeli, Ordu, İzmir, Malatya, Muğla, Adana, Gaziantep, Kayseri, Ankara, Eskişehir, Balıkesir ve Mersin gibi büyükşehir belediyelerinin yanı sıra Çorum, Elazığ, Niğde, Osmaniye, Zonguldak, Ardahan ve Uşak il belediyelerinde yürütüldüğü görülmektedir. İnşaat ve yıkıntı atıklarının yönetimi ile ilgili Bursa, Eskişehir, Gaziantep, Malatya, Mersin, Osmaniye, Sakarya ve Batman illerinde geri kazanım çalışmaları yapılmaktadır. Ulusal Atık Yönetimi Eylem Planı'nda 2014 yılında yaklaşık 100 milyon tonun üzerinde hafriyat toprağı, inşaat ve yıkıntı atı̆̆ı geri kazanıldığı ya da bertaraf edildiği belirtilmekte, 2023 yılında ise 300 milyon ton hafriyat toprağı, inşaat ve yıkıntı atığı oluşması beklenmektedir (URL-24 2018). Yapılan değerlendirmelerle ülkemizde yapısal atıkların miktarı, niteliği, içeriği, yeniden kullanım, geri dönüşüm ve geri kazanım oranları konusunda yeterli düzeyde sayısal verinin bulunmadığı açıkça görülmektedir. Bu durum, ülkemizde atık yönetimi konusunda yapılan çalışmaların eksikliğine işaret etmektedir.

Bina sertifikasyon sistemleri bakımından ise dünya genelinde geçerli olan sertifikaların ülkemizde de kullanıldı̆̆ 1 görülmektedir. Bu sertifikaların alınması konusunda mevzuatta bir zorunluluk ya da teşvik bulunmamaktadır. Öte yandan 2017 yılında 30279 sayılı Resmi Gazete'de yayınlanarak yürürlüğe giren Binalar ile Yerleşmeler İçin Yeşil Sertifika Yönetmeliği kapsamında Ulusal Yeşil Sertifika Bilgi Sistemi (YeS-Tr) üzerinden bina derecelendirmesi yapılmaktadır.

\section{Sonuçlar ve Öneriler}

2017 yll itibariyle inşaat sektörünün Türkiye ekonomisindeki yeri \%9 düzeyindedir. 2025 yılında ise gelişmekte olan ülkelerde inşaat sektörünün gelişiminin \%17 seviyesine ulaşılacağı tahmin edilmektedir (URL-25 2018). Buna dayanarak artan nüfusun fiziki mekan ihtiyacı ve hızlanan yapılaşma faaliyeti sonunda yakın gelecekte ülkemiz ve gelişmekte olan diğer ülkeler için yapısal atıkların oldukça önemli bir çevre problem haline geleceğini göstermektedir. Çalışma kapsamında ilgili mevzuatın değerlendirilmesiyle elde edilenler ışığında şunları söyleyebiliriz;

- Gelişmiş̧ ülkeler, yapısal atıkların kaçak yollarla doğal kaynakları kirletmesini önlemek için katı kurallar ve caydırıcı cezalar getirmiştir.

- Hong Kong Hükümeti; yapılaşmanın getirdiği çevre sorunlarını önlemek için inşaat firmalarına ISO standartlarından 14000serisini zorunlu kılmaktadır. Böylece yapısal atık sorununu çözümlemiş̧ir.

- Yapı sertifikasyon sistemleri çevre duyarlı yapıları ve yapısal atıkların değerlendirilmesini desteklemektedir. Sertifikasyon sistemleri kaynak kullanımı azaltarak yapısal atık oluşumunun önlenmesine destek olmaktadır. 
- Japonya Hükümeti, atık yerine yan ürün kavramı geliştirerek devlet tarafından belirli bir enstitü tarafından üretmektedir. Bu çevre dostu ürünlerin alımını zorunlu tutmaktadır. Ayrıca özel sektörü, geri dönüşüm ve tasnif yapıları için teşvik edici ve harekete geçirici eylemler sağlamıştır.

- Avrupa Birliği üye ülkeler Atık Çerçeve Direktifi ile 2020 yılında \%70 geri dönüşüm oranını hedeflemektedir. Bu direktifi her üye ülke kendine göre düzenleme getirip hedeflenen geri dönüşüm değerine ulaşılması beklenmektedir.

- Ülkemizde; Hafriyat, İnşaat ve Yıkıntı Atıkların Kontrolü Yönetmeliği ile seçici yıkımın esas olmasına rağmen buna yönelik geri dönüştürme ve yıkım planı gibi bir düzenleme bulunmamaktadır.

- Aynı yönetmelik ile yapısal atıkların en aza indirilmesi esas olmasına rağmen proje aşamasından yıkım sürecine kadar uygulayıcı bir düzenleme bulunmamaktadır.

- Yapısal atıkların oluşumundan bertarafına kadar kapsayan tüm faaliyetlerden Bakanlık, Mülki Amirler ve Belediyeler sorumluluk altındadır. Bu durum kimi zaman yetki karmaşasına yol açmaktadır. Gelişmiş ülkelerde özel girișim firmaları yetkilendirilerek denetim sağlanmaktadır.

Ülkemizde konuyla ilgili mevcut mevzuat Avrupa Birliğine uyum çerçevesinde hazırlanmış fakat ülke genelinde uygulanması konusu ne yazık ki yaygınlaştırılamamıştır. Uygulama, denetim ve izleme faaliyetleri ilgili kurumlarca yetersiz kaldığı düşünülmektedir. Ülkemizde de atık yönetimi hiyerarşisi benimsenmekle birlikte, uygulamada ne yazık ki bu durumun geçerli olmadığı görülmektedir. Özellikle yapısal atıklar konusunda istatistiki verinin azlığı, yapısal atık dönüşüm merkezlerinin yaygın olmayışı ve artan kentsel yapılaşma dikkate alındığında atıkların, en son tercih edilecek yol olan, depolanarak bertaraf edildiği kanısı oluşmaktadır.

İlgili mevzuatın uygulamaya yönelik eksiklerinin giderilmesi ve geri dönüşümün yaygınlaşması için çeşitli öneriler geliştirilmiştir. Bunlar;

- Ülkemizde atıkların yasadışı dökümünün önüne geçilmesi için caydırıcı düzenlemeler yapılmalı, kontrollü düzenli depolama sahalarının kullanılması sağlanmalıdır. Bilindiği gibi olması gereken daha çok geri dönüşüm sağlamak ve minimum düzeyde depolama yapmaktır. Bu nedenle yapısal atık geri dönüşüm tesislerinin yaygınlaştırılmasına ihtiyaç vardır.

- Geri dönüşümle sağlanacak üretiminde Japonya'da olduğu gibi yan ürün kavramı geliştirilip, devlet eliyle dönüşüm desteklenerek, kamu ve özel teşebbüs inşaatlarında yan ürünlerin kullanımı teşvik edilmelidir.

- Atık yönetiminin ve kontrolünün sağlanabilmesi, gelecek projeksiyonunun yapılabilmesi ve yapısal atıkların geri dönüşümü konusunda ulaşılan noktanın bilinebilmesi için yapısal atık miktarları ve niteliği konusunda sayısal verinin oluşturulması gerekmektedir.

- İnşaat sektöründeki firmalara ISO 14000 serisi zorunlu kılınmalıdır.

- Yıkım ruhsatı verilmeden önce geri dönüşüm ve kullanım/yıkım planı idareye sunulmalı ve yetkilendirilmiş firmalar ile denetimi yapılmalıdır. Böylece atık takibi sağlanabileceği düşünülmektedir.

- İnşaat yapımı sırasında oluşan yapısal atıklar, yapı denetim firmalarının resmi olarak takibine alınmalıdır.

- Yapısal atık oluşumu önlenmesi veya azaltılmasına yönelik yaklaşımlar ülke mevzuatınca desteklenmeli ve yapı ruhsatı aşamasında özellikle yapım aşamasında oluşacak atık miktarının önüne geçebilmek için kullanılacak parçalı malzeme boyutunun seçiminde mahal boyutu karşılaştırmalı olarak irdelenmelidir.

- Atık önlemeye ve azaltılmasına yönelik çalışmaların yanı sıra özellikle geri dönüşüm oranının arttırılabilmesi için ar-ge çalışmalarına öncelik verilmeli ve desteklenmelidir.

İnsan yaşamının büyük kısmı yapılaşmış çevrede geçmektedir. Yapılaşmış çevreyi inşa etmede kullanılan ürünlerin çevre dostu olması ve tekrar kullanılması dünyamızın sürdürülebilirliği için hassasiyetle üzerinde durmak her birey için temel sorumluluktur. Bu nedenle ülkelerin; çevre politikalarında bu konuya özel önem göstermesi, mevzuat ve yönetmeliklerin hassas biçimde uygulamaya geçirilmesi en önemli görevi olduğu unutulmamalıdır.

\section{Teşekkür}

Çalışmada kullanılan bazı verilerin temini konusunda desteklerinden dolayı Sayın Dilan ÇİFTÇİ ve Sayın Gizem BEYHAN'a teşekkür ederiz.

\section{Kaynaklar}

Arslan H., Coşgun N., Salgın B., (2012), Construction and demolition waste management in Turkey, Waste Management İçinde, (L.F.M. Rebellon, Ed.), Intechopen, ss:313-332. https://www.intechopen.com/books/waste-management-an-integratedvision/construction-and-demolition-waste-management-in-turkey, [Erişim 15 Ağustos 2019].

AYY, (2015), Atık Yönetimi Yönetmeliği, Resmi Gazete, Tarih: 02.04.2015, Say1: 29314, https://www.resmigazete.gov.tr/eskiler/ 2015/04/20150402-2.htm, [Erişim 20 Aralık 2018].

Behera M., Bhattacharyya S.K., Minocha A.K., Deoliya R., Maiti S., (2014), Recycled aggregate from C\&D waste \&its use in concrete - A breakthrough towards sustainability in construction sector: A review, Construction and Building Materials, 68, 501-516.

EU, (2019), Living well, within the limits of our planet, European Union, http://www.webcitation.org/query?url=http\%3A\%2F\%2 Fec.europa.eu\%2Fenvironment\%2Fpubs\%2Fpdf\%2Ffactsheets\%2F.7eap\%2Fen.pdf\&date=2017-07-18, [Erişim 02 Mart 2019 ]. 
EPA, (2019), How To GreenScape, https://archive.epa.gov/wastes/conserve/tools/greenscapes/web/html/howto.html, [Erişim 10 Ağustos 2019].

Gao A.M.Z., (2018), Construction \& demolition waste management: from Japan to Hong Kong, https://papers.ssrn.com/sol3/papers. cfm?abstract id=1131984, [Erişim 10 Ağustos 2019].

Güler A.Ü., (2018), Sürdürülebilir afet yönetiminde atık yönetimi, Doğal Afetler ve Çevre Dergisi, 4(2), 236-246.

HIYAKY, (2004), Hafriyat Topră̆ı, Inşaat ve Yıkıntı Atıklarının Kontrolü Yönetmeliği, Resmi Gazete, Tarih: 18.03.2004, Sayı: 25406, http://www.mevzuat.gov.tr/Metin.Aspx?MevzuatKod=7.5.5401\&MevzuatIliski=0\&sourceXmlSearch=hafriyat, [Erişim 18 Ocak 2019].

Huang B., Wang X., Kua H., Geng Y., Bleischwitz R., Ren J., (2018), Construction and demolition waste management in China through the $3 R$ principle, Resources, Conservation \& Recycling, 129, 36-44.

Kılıç N., (2012), Kentsel dönüşümde geri dönüşüm atağl, İzmir Ticaret Odas1, AR\&GE Bülten, ss.12-20, http://www.izto.org.tr/ portals/0/argebulten/6kentseldonusumatagi.pdf, [Erişim 12 Ağustos 2019].

Kotan S., (2016), Yıkım işlemleri ve Hafriyat Toprağı ile İnşaat ve Yıkıntı Atıklarının Kontrolü Yönetmeliği taslağl, Yaşanabilir Çevreler ve Marka Şehirler, Hedef 2023, Demolition Conference İstanbul, Turkey. https://www.khl-group.com/events/demolitionconference-turkey/assets/suna-kotan.pdf, [Erişim 24 Mayıs 2019].

Limoncu S., Biçer Özkul, Ü., (2012), Yapısal atık oluşumu ve atıkların yönetimi, Mimarlıkta Malzeme, 7(22), 30-34.

Osmani M., (2012), Construction waste minimization in the UK: Current pressures for change and approaches, Procedia - Social and Behavioral Sciences, 40(2012), 37-40.

Öztürk M., (2005), İnşaat yıkıntı atıkları yönetimi, Çevre ve Orman Bakanlığı, Ankara, http://www.tucev.org, [Erişim 18 Ocak 2019].

Salgın B., (2015), Yapı yaşam süreçlerinde yapısal atıkların önlenmesine/azaltılmasına yönelik tasarım yaklaşımları ve bir model önerisi, Doktora Tezi, Yıldız Teknik Üniversitesi Fen Bilimleri Enstitüsü, İstanbul.

URL-1, (2018), Tarih Boyu Sürdürülebilirlik Kavramı ve Açıklamaları, http://ekolojist.net/tarih-boyu-surdurulebilirlik-kavrami aciklamalari/, [Erișim 15 Aralık 2018].

URL-2, (2018), Sifir Atık Projesi, https://www.sifiratik.gov.tr, [Erişim 20 Aralık 2018].

URL-3, (2018), Ekolojik Ayak İzi, https://www.ekolojist.net, [Erişim 25 Aralık 2018].

URL-4, (2018), Ekolojik Ayak izi, https://data.footprintnetwork.org/\#/countryTrends?cn=223\&type=BCpc,EFCpc, [Erişim 25 Aralık 2018].

URL-5, (2018), İznik Gölündeki kirlilik, https://www.istanbulhaber.com.tr/iznik-golundeki-kirlilik-meclis-gundeminde-haber331716.htm, [Erişim 12 Aralık 2018].

URL-6, (2018), Belgrad Ormant, https://www.emlaktasondakika.com/haber/genel/belgrad-ormanina-moloz-dokup-kaciyorlar/ 122920, [Erişim 8 Aralık 2018].

URL-7, (2018), Çevre ve Şehircilik Bakanlı̆̆l, https://csb.gov.tr/bakan-kurum-bakanligimizin-eylem-plani-yuzde-98-basariylatamamlandi-bakanlik-faaliyetleri-25378, [Erişim 8 Aralık 2018].

URL-8, (2017), İstanbul İli 2017 Yll Çevre Durum Raporu, https://webdosya.csb.gov.tr/db/ced/icerikler/-istanbul_2017_cevre_ durum_raporu-20181126105204.pdf, [Erișim 1 Şubat 2019].

URL-9, (2017), Adana İli 2017 Yllı Çevre Durum Raporu, https://webdosya.csb.gov.tr/db/ced/icerikler/adana_cevre_durum_ raporu_2017_son-20181001151954.pdf, [Erişim 1 Şubat 2019].

URL-10, (2017), Konya İli 2017 Yll Çevre Durum Raporu, https://webdosya.csb.gov.tr/db/ced/icerikler/son-konya-il--2017-yilicevre-durum-raporu-20180807103212.pdf, [Erișim 1 Şubat 2019].

URL-11, (2017), Trabzon İli 2017 Yllı Çevre Durum Raporu, https://webdosya.csb.gov.tr/db/ced/icerikler/2017_trabzon_cdr_son20180912145039.pdf, [Erişim 1 Şubat 2019].

URL-12, (2017), Malatya İli 2017 Yll Çevre Durum Raporu, https://webdosya.csb.gov.tr/db/ced/icerikler/son-malatyacevredurum raporu_2017-20180718160733.pdf, [Erişim 1 Şubat 2019].

URL-13, (2017), Hatay Ili 2017 Yll Çevre Durum Raporu. https://webdosya.csb.gov.tr/db/ced/icerikler/son-hatay2017-cevre-durumraporu-11.07.2018-20180723155526.pdf, [Erişim 1 Şubat 2019].

URL-14, (2017), Manisa İli 2017 Yll Çevre Durum Raporu, https://webdosya.csb.gov.tr/db/ced/icerikler/son1-manisa20181001151132.pdf, [Erişim 1 Şubat 2019].

URL-15, (2016), Eurostat, env_wasgen, https://ec.europa.eu/eurostat/statistics-explained/index.php?title=File:Waste_generation_ by_economic_activities_and_households,_EU-28,_2016_(\%25).png\&oldid=413561, [Erişim 11 Ağustos 2019].

URL-16, (2016), Eurostat, env_wasgen, http://appsso.eurostat.ec.europa.eu/nui/show.do?dataset=env_wasgen\&lang=en, [Erişim 11 Ağustos 2019].

URL-17, (2018), Atıkların Doğada Yok Olma Süreleri, https://www.kucukpara.com/banka-kartlari/atiklar-ne-kadar-surede-yok-olurdogada-zor-yok-olan-maddeler/, [Erișim 28 Aralık 2018].

URL-18, (2018), Inşaat Ylkımı, http://www.demirciogluhurdacilik.com/?newUrun=1\&Id=1705333\&CatId=bs857281\&Fstate=\&/ Bina-Y\%C4\%B1k\%C4\%B1m\%C4\%B1, [Erişim 28 Aralık 2018].

URL-19, (2019), Sustainable building materials made from waste, https://www.stonecycling.com/\#wastebasedbrick, [Erişim 28 Nisan 2019].

URL-20, (2019), Directive 2008/98/EC on waste (Waste Framework Directive), https://ec.europa.eu/environment/waste/framework/, [Erişim 11 Ağustos 2019].

URL-21, (2018), Commission staff working document, measuring progress towards circular economy in the European Union-Key indicators for a monitoring framework, https://ec.europa.eu/environment/circular-economy/pdf/monitoring-framework_staffworking-document.pdf, [Erişim 10 Ağustos 2019].

URL-22, (2014), History and current state of waste management in Japan, https://www.env.go.jp/en/recycle/smcs/attach/ hcswm.pdf, [Erişim 15 Ağustos 2019].

URL-23, (2017), Environmental Management System, https://www.epd.gov.hk/epd/english/how_help/tools_ems/iso14001.html, [Erişim 6 Şubat 2019]. 
URL-24, (2018), Ulusal Atık Yönetimi Eylem Planı, https://webdosya.csb.gov.tr/db/cygm/haberler/ulusal_at-k_yonet-m--eylem_plan-20180328154824.pdf, [Erişim 20 Aralık 2018].

URL-25, (2018), Sektörel Bakış, https://assets.kpmg/content/dam/kpmg/tr/pdf/2018/01/sektorel-bakis-2018-insaat.pdf, [Erişim 20 Aralık 2018].

URL-26, (2007), Türkiye'de atık yönetimi, ulusal düzenlemeler ve uygulama sonuçlarının değerlendirilmesi, Performans Denetim Raporu, T.C. Sayıştay Başkanlığı, https://docplayer.biz.tr/29224-T-c-sayistay-baskanligi-turkiye-de-atik-yonetimi-ulusalduzenlemeler-ve-uygulama-sonuclarinin-degerlendirilmesi-performans-denetimi-raporu.html, [Erişim 6 Şubat 2019].

Wu Z., Yu A.T.W., Shen L., Liu G., (2014), Quantifying construction and demolition waste: An analytical review, Waste Management, 34(9), 1683-1692.

Zhao W., Leeftink R.B., Rotter S., (2008), Construction and demolition waste management in China: analysis of economic instruments for solving a growing problem, Waste Management and the Environment IV İçinde (M. Zamorano, C.A. Brebbia, A. Kungolos, V. Popov, H. Itoh, Eds.), WIT Press, Boston, ss.471-480.

Bu çalışma, sorumlu yazarın Doç. Dr. Onur ERMAN'ın danışmanlığında ÇÜ Fen Bilimleri Enstitüsü Mimarlık Anabilim Dalı'nda sürdürmekte olduğu doktora çalışması kapsamında hazırlanmıştır. 